\title{
Comparison Analysis Of Cost And Time In Situ Concrete Implementation Method With Pre Cast
}

\author{
Andrew Samuel Erionkita Purba \\ Department Of Civil Engineering, University Of North Sumatra, Jl. Dr. Mansur No. 9 Padang Bulan, Kec. \\ Medan Baru, Kota Medan 20222
}

\begin{tabular}{|c|c|}
\hline ARTICLE INFO & ABSTRACT \\
\hline Article history: & In the implementation of construction projects, there are several \\
\hline $\begin{array}{r}\text { Received Aug 06, } 2020 \\
\text { Revised Sep 15, } 2020 \\
\text { Accepted Oct 30, } 2020\end{array}$ & $\begin{array}{l}\text { methods of concrete implementation used, such as in situ concrete } \\
\text { which is carried out in the implementation of casting at the project } \\
\text { site so that it takes a long time and quite a lot of formwork. In } \\
\text { addition, there is also a method of implementing pre-cast concrete }\end{array}$ \\
\hline $\begin{array}{r}\text { Keywords: } \\
\text { Abutments } \\
\text { In Situ } \\
\text { Pre Cast } \\
\text { Cost } \\
\text { Time }\end{array}$ & $\begin{array}{l}\text { production process is carried out in a special place for pre-cast } \\
\text { production and then brought to the project site and installed into } \\
\text { concrete to form a unified structure. So it doesn't take too long and is } \\
\text { considered more efficient. This study aims to compare the cost and } \\
\text { time of implementing in situ and pre-cast concrete methods on one } \\
\text { of the bridge abutments of the Kuala Tanjung Multi Purpose } \\
\text { Terminal Project using the data obtained in the form of image data, } \\
\text { material prices, wages and equipment. And from the results of the } \\
\text { calculation analysis, the results of the method of implementing } \\
\text { concrete on one of the bridge abutments are that with in situ } \\
\text { concrete it takes } 7 \text { days to implement with a total cost of Rp. } \\
807,867,550 \text {, - and with pre cast concrete it takes } 5 \text { days to } \\
\text { implement total cost Rp.612,345,190,-. So from this study, it was } \\
\text { found that the comparison method for the implementation of pre-cast } \\
\text { concrete was more efficient with a cheaper price comparison of Rp. } \\
\text { 195.552.360, - and } 2 \text { days faster time for the work of one bridge } \\
\text { abutment. }\end{array}$ \\
\hline
\end{tabular}

This is an open access article under the CC BY-NC license.

Corresponding Author:
Andrew Samuel Erionkita Purba,
Department Of Civil Engineering,
University Of North Sumatra,
Jl. Dr. Mansur No. 9 Padang Bulan, Kec. Medan Baru, Kota Medan 20222 .
Email : samuelpurba@gmail.com
1. INTRODUCTION
The development of the construction world is currently growing rapidly, this can be seen by the
increasing number of developments carried out, both buildings, roads, bridges and buildings for
community needs. Each construction process also takes sufficient time to complete it from start to
finish. Therefore, careful thought is needed to determine the most suitable and efficient
implementation method in completing a construction project, also through good cooperation
between the various parties involved, especially for large projects such as high-rise buildings. The
role of construction management is also needed so that the utilization of existing resources can be
maximized.


In the implementation of a construction, many efforts are usually made to improve the quality of work and the quantity of work both structurally and in construction management. Usually in the implementation of a construction project, the larger the project, the greater the obstacles faced by the construction service company. Therefore, construction service companies must have careful planning in the implementation of a construction project.

One thing that must also be considered is the concrete design. Concrete is one of the most widely used construction materials in Indonesia, when compared to the use of other materials such as wood and wood steel. This is understandable because the ingredients for the formation are easily available in Indonesia, quite durable, easy to shape and the price is also relatively affordable.

Usually there are several alternative implementation methods used such as the cast in situ / conventional method which is carried out at the project site, but this method usually has several drawbacks such as requiring a long time, poor quality control, requiring a lot of formwork and workers so that it is felt less efficient in terms of cost and time.

This research has also been investigated previously which has been published in technical journals (Fahrizal Fani, et al. 2012) with the title "Comparative Analysis of Cast in Situ Implementation Methods with Precast against Cost and Time on the Dian Regency Apartment project" which proves that the in situ method requires implementation time of 396 days at a cost of Rp. $25,887,838,200$, -, and the precast method with a execution time of 245 days at a cost of Rp. $27,274,827,600,-$. So the difference in the percentage of the price reached $5.09 \%$ while the implementation time reached $38.1 \%$.

Then according to a literature study (Indah purwaningsih, et al. 2014) which compares conventional concrete with fly slab concrete that the use of conventional concrete takes 150 days at a cost of Rp. 632.106.000,--, while using fly slab concrete takes time 135 days at a cost of Rp. $615.366 .000,-$. So that the difference in the percentage of the price reaches $2.65 \%$ while the implementation time reaches $10 \%$.

In addition, according to a literature study (Candy HN, et al. 2016) which compares the time and cost of pre-cast plates with conventional ones, it takes 198 days to implement pre-cast plates at a cost of Rp. 30.352.740,-, while on conventional plates it takes 226 prices at a cost of Rp. $30,230,145,000,-$. So that the difference in the percentage of the price reaches $0.4 \%$ while the implementation time reaches $12.4 \%$.

So, as it is known that in situ concreting on abutments takes longer and requires quite a lot of manpower. So if you use the pre-cast construction method, it is one solution to save time and also the required labor and is also more efficient in construction sites with extreme areas such as in the ocean area.

\section{RESEARCH METHOD}

The research method is a way to find out something with systematic steps to achieve optimal results and this research uses a case study method, which is to find a cheaper and more efficient price and time from abutment concrete comparisons by in situ and pre-cast in a Multi Purpose Terminal Project. Kuala Tanjung by using analysis based on SNI.

\subsection{Research Description}

This case study takes the research location at the Kuala Tanjung Village Pier Multi Purpose Terminal Project, Inalum Road Access Road, Batubara Regency, Sei Suka District.

In this study, researchers examined one of the trestle girder abutments in the Kuala Tanjung Multi Purpose Terminal Project owned by PT. Prima Multi Terminal with a total project value of Rp. $2,432,307,167,999$, - and the processing time is 960 days.

\subsection{Field survey}

At this stage, the research location that will be reviewed is checked. This check is carried out with the aim of knowing how the field conditions are and what is needed to conduct research.

\subsection{Study of literature}

At this stage, a literature study is carried out with the aim of obtaining the basic knowledge and rules that will be used to design the steps for data collection and processing. This literature 
study can be in the form of theoretical foundations, methods that will be used in processing data, as well as research results that will be carried out previously which are related and support the research itself.

\subsection{Data collection}

To achieve the research objectives, data is needed to be used to be processed according to the theoretical basis obtained. The data itself is divided into two; primary data and secondary data. Primary data in the form of data obtained and collected through surveys directly to the research site. Secondary data can be obtained by searching through the internet, co-workers or visiting the offices or agencies concerned. In this study, researchers only used secondary data.

\section{RESULTS AND DISCUSSIONS}

\subsection{Materials and Wages Analysis}

Material analysis of a job is to calculate the amount/volume of each material, as well as the amount of cost required. Meanwhile, what is meant by analyzing the wages of a job is to calculate the amount of energy needed, as well as the amount of costs required for the job (H.bachtiar. 1993).

Material analysis of a job can be calculated using SNI analysis. This SNI analysis is issued by the Center for Settlement Research and Development. The SNI analysis is an update of the 1921 BOW analysis (Burgeslijke Openbare Werken). Based on the SNI analysis, the coefficients of materials, wages and tools have been determined to analyze the prices or costs required in making the unit price of work. The composition of the comparison and composition of materials, wages for labor and equipment for a job has also been determined in the SNI and then multiplied by the prevailing market price based on each work unit.

In the SNI cost analysis, the labor index and the building materials index used are general for each job throughout Indonesia. But in reality, of course, there are differences in labor productivity in each region and the use of building materials/materials in each project. This clearly results in differences in the labor index and building materials index in each project.

Unit wage analysis is the calculation of the number of workers and the cost of wages needed to complete a project. The unit price of wages varies in each region. So, each region has its own $\mathrm{SNI}$ to determine the amount of labor and the required wage costs.

\subsection{Data on Material Prices, Wages, and Equipment}

Data on the prices of materials, wages and equipment for the A1 abutment work to be analyzed are obtained from PT. PP (Persero) Tbk., as follows:

Table 1. Price List

\begin{tabular}{|c|c|c|c|c|}
\hline & & TYPE OF WORK & : & Abutment A.1 \\
\hline \multicolumn{2}{|c|}{ NO } & $\begin{array}{l}\text { DESCRIPTI } \\
\text { ON }\end{array}$ & UNIT & $\begin{array}{l}\text { UNIT PRICE } \\
(\mathbf{R p})\end{array}$ \\
\hline \multirow[t]{2}{*}{1} & & Ingredients & & \\
\hline & M17.0007 & K-450. Concrete & m3 & $1,898,568$ \\
\hline \multirow[t]{8}{*}{2} & & Equipment & & \\
\hline & E090001 & Concrete Bucket & o'clock & 44,361 \\
\hline & E020003 & Anchor Boat & o'clock & 835,161 \\
\hline & E030005 & Crawler Crane 65 tons & o'clock & $1,129,615$ \\
\hline & E030003 & Crawler Crane 40 tons & o'clock & 742.870 \\
\hline & E00.0002 & Pontoon 120 feet +Winch & o'clock & $2,162,401$ \\
\hline & E010001 & 100 feet pontoon & o'clock & $1,212,974$ \\
\hline & E09,0004 & Concrete Vibrator & o'clock & 29,037 \\
\hline
\end{tabular}




\begin{tabular}{ccccc}
\hline & E09,0003 & Concrete mixer truck & o'clock & \\
& & Wages & & \\
& P3 & Worker & man/day & 110,750 \\
& P11 & Foreman & man/day & 166.125 \\
4 & P14 & Operator Assistant & man/day & 134,482 \\
& S080001 & Work & m2 & 928,799 \\
& S080001a & Marine Insitu Formwork (Bottom) & m2 & 501.317 \\
\hline
\end{tabular}

\subsection{Concrete Time Analysis}

Analysis of the execution time of each work activity is calculated by dividing the volume of work by the value of the productivity of workers/tools. Then to find out the duration of the overall concrete implementation using data obtained from the field and then calculating the total duration of time.

\subsection{In Situ Concrete Time}

Based on the data that has been obtained from PT. PP (Persero) Tbk., that in in situ concrete work there are 3 kinds of work, then the the working time in 1 day is 7 hours, with the number of workers as many as 20 people. The following is the result of the calculation of the time for the in situ abutment concreting work:

a. Formwork installation is calculated by knowing that one worker can complete formwork work as much as $0.73 \mathrm{~m} 2 /$ hour. Then the total duration is the volume divided by the product of the number of workers and the productivity of labor.

b. The installation of iron is calculated knowing that one worker can work $54 \mathrm{~kg}$ of iron per hour. Then the total duration is the total time starting from the initial assembly, loading to the pontoon, distribution of the pontoon from the coast to the abutment location, and finally the installation of iron reinforcement.

c. Concrete work is calculated by adding up the time starting from the arrival of the mixer truck, pouring it into the pontoon, the distribution of the pontoon from the beach to the abutment location, and finally placing the concrete in situ.

Table 2. Implementation Time of In Situ Concrete

\begin{tabular}{|c|c|c|c|c|c|c|c|}
\hline \multicolumn{8}{|c|}{$\begin{array}{c}\text { Time Schedule for In Situ Concrete } \\
\text { Works }\end{array}$} \\
\hline Days to- & 1 & 2 & 3 & 4 & 5 & 6 & 7 \\
\hline $\begin{array}{l}\text { Formwork } \\
\text { Installation }\end{array}$ & & & & & & & \\
\hline Iron Installation & & & & & & & \\
\hline Concrete & & & & & & & \\
\hline
\end{tabular}

\subsection{Pre-Cast Concrete Time}

It is the same with the analysis of pre-cast concrete time, that in pre-cast concrete work there are 3 types of work, with the length of time working in 1 day is 7 hours, and the number of workers is 20 people. The following are the results of the calculation of the pre-cast abutment work time:

a. Formwork installation is calculated by knowing that one worker can complete formwork work as much as $0.73 \mathrm{~m} 2 /$ hour. Then the total duration is the volume divided by the product of the number of workers and the productivity of labor.

b. The installation of iron is calculated knowing that one worker can work $54 \mathrm{~kg}$ of iron per hour. Then the total duration is the total time starting from the initial assembly, loading to the pontoon, distribution of the pontoon from the coast to the abutment location, and finally the 
installation of iron reinforcement.

c. Concrete work is calculated by adding up the time starting from the arrival of the mixer truck, pouring it into the pontoon, the distribution of the pontoon from the beach to the abutment location, and finally placing pre-cast concrete.

Table 3. Analysis of Pre Cast Concrete Time

\begin{tabular}{|c|c|c|c|c|c|}
\hline \multicolumn{6}{|c|}{$\begin{array}{c}\text { Analysis of pre-cast concrete time with } 7 \\
\text { working hours/day }\end{array}$} \\
\hline \multicolumn{6}{|l|}{$\begin{array}{c}\text { A. Formwork Installation } \\
1 \text { worker can complete } 0.73 \\
\text { m2/hour }\end{array}$} \\
\hline & the number of workers & productivity & volume & \multicolumn{2}{|l|}{$\underset{\text { s) }}{\text { duration(hour }}$} \\
\hline middle formwork & 20 & 0.73 & 58,785 & \multicolumn{2}{|l|}{4.026369863} \\
\hline wall formwork & 20 & 0.73 & 45.058 & \multicolumn{2}{|l|}{3.086164384} \\
\hline TOTAL & & & & \multicolumn{2}{|l|}{7.112534247} \\
\hline \multicolumn{6}{|l|}{ B.concrete work } \\
\hline & truck mixer $6 \mathrm{~m} 3 / 15 \mathrm{~min}$ & pouring & pontoon & casting & total \\
\hline \multirow[t]{2}{*}{ productivity for $131.356 \mathrm{~m} 3$} & 0.041666667 & 0.002777778 & 0.020833333 & \multirow{2}{*}{\multicolumn{2}{|c|}{$\begin{array}{l}0.016666667 \\
2.16666666710,6527778\end{array}$}} \\
\hline & 5,416666667 & 0.361111111 & 2.708333333 & & \\
\hline C.Iron Work & \multicolumn{2}{|c|}{1 worker can finish $54 \mathrm{Kg} /$ hour } & & & \multirow{4}{*}{$\begin{array}{c}\text { total } \\
\text { duration } \\
12.8448056\end{array}$} \\
\hline & initial assembly & loading & pontoon & install & \\
\hline iron $12882.39 \mathrm{Kg}$ & 11.92813889 & 0.166666667 & 0.5 & 0.25 & \\
\hline total time duration & $\begin{array}{c}\text { o'clock } \\
30.61011758\end{array}$ & $\begin{array}{c}\text { day } \\
\mathbf{4 . 3 7 2 8 7 3 9 4}\end{array}$ & & & \\
\hline
\end{tabular}

From the results of these calculations, it is found that the time needed to work on pre-cast abutments is about 5 days. The following is the implementation time table:

Table 4. Implementation Time of Pre Cast Concrete

$\begin{aligned} & \text { Time Schedule of Pre Cast Concrete Works } \\ & \text { Days to- }\end{aligned} \quad 1$
$\begin{aligned} & \text { Formwork Installation } \\ & \text { Iron Installation } \\ & \text { Concrete }\end{aligned}$

\subsection{Concrete Cost Analysis}

The calculation of unit prices for in situ and pre-cast concrete abutments was analyzed based on data obtained from sketch drawings and data on wages, materials and equipment prices and then calculated the volume of abutments, as well as the amount of formwork and steel reinforcement used.

Table 5. Total Pre Cast Abutment Reinforcement

\begin{tabular}{ccccccc}
\hline \multicolumn{7}{c}{ Pre-Cast Repair } \\
\hline No. & Type of Tul & Long & Amount & Diameter & Weight/m & Volume \\
& & $\mathrm{m}$ & $\mathrm{bra}$ & $\mathrm{mm}$ & $\mathrm{kg}$ & $\mathrm{kg}$ \\
1 & $\mathrm{P} 1$ & 6.33 & 44 & 19 & 2.225565 & 619,8644 \\
2 & $\mathrm{P} 1 \mathrm{~A}$ & 9.3 & 4 & 19 & 2.225565 & 82.79102 \\
3 & $\mathrm{P} 2$ & 6.57 & 20 & 19 & 2.225565 & 292.4392 \\
4 & $\mathrm{P} 2 \mathrm{a}$ & 6.4 & 24 & 19 & 2.225565 & 341.8468 \\
\hline
\end{tabular}




\begin{tabular}{ccccccc}
\hline 5 & P2b & 9.54 & 22 & 19 & 2.225565 & 467,1016 \\
6 & P2c & 9.3 & 22 & 19 & 2.225565 & 455,3506 \\
7 & P3 & 2.72 & 20 & 19 & 2.225565 & 121.0707 \\
8 & P3a & 2.65 & 24 & 19 & 2.225565 & 141.5459 \\
9 & P4 & 5.45 & 80 & 13 & 1.041885 & 454,2619 \\
10 & P5 & 5.66 & 30 & 19 & 2.225565 & 377,9009 \\
11 & P5c & 5.45 & 126 & 19 & 2.225565 & 1528,295 \\
12 & P6 & 6 & 84 & 13 & 1.041885 & 525.11 \\
13 & P6c & 6 & 21 & 13 & 1.041885 & 131.2775 \\
14 & P7 & 4 & 64 & 13 & 1.041885 & 266,7226 \\
15 & P7A & 4 & 64 & 13 & 1.041885 & 266,7226 \\
16 & P9 & 5.87 & 8 & 13 & 1.041885 & 48,92692 \\
17 & P9A & 9.06 & 4 & 13 & 1.041885 & 37,75791 \\
18 & $\mathrm{P} 12$ & 4 & 158 & 16 & 1.57824 & 997,4477 \\
19 & P13 & 4.1 & 158 & 19 & 2.225565 & 1441,721 \\
& TOTAL & & & & & 8598,155 \\
\hline
\end{tabular}

Table 5. In Situ Repair For Pre Cast

\begin{tabular}{ccccccc}
\hline No. & Type of Tul & $\begin{array}{c}\text { Long } \\
\mathrm{m}\end{array}$ & $\begin{array}{c}\text { Amount } \\
\text { bra }\end{array}$ & $\begin{array}{c}\text { Diameter } \\
\mathrm{mm}\end{array}$ & $\begin{array}{c}\text { Weight/m } \\
\mathrm{kg}\end{array}$ & $\begin{array}{c}\text { Volume } \\
\mathrm{kg}\end{array}$ \\
\hline 1 & $\mathrm{P} 1 \mathrm{~A}$ & 9.3 & 18 & 19 & 2.225565 & 372.5596 \\
2 & $\mathrm{P} 4$ & 5.45 & 14 & 13 & 1.041885 & 79.49583 \\
3 & $\mathrm{P} 5$ & 5.66 & 26 & 19 & 2.225565 & 327.5141 \\
4 & $\mathrm{P} 6$ & 6 & 4 & 13 & 1.041885 & 25.00524 \\
5 & $\mathrm{P} 6 \mathrm{a}$ & 6 & 14 & 13 & 1.041885 & 87.51834 \\
6 & $\mathrm{P} 7$ & 4 & 10 & 13 & 1.041885 & 41.6754 \\
7 & $\mathrm{P} 7 \mathrm{~A}$ & 4 & 10 & 13 & 1.041885 & 41.6754 \\
8 & $\mathrm{P} 8$ & 19.8 & 5 & 19 & 2.225565 & 220.3309 \\
9 & $\mathrm{P} 10$ & 19.03 & 2 & 13 & 1.041885 & 39.65414 \\
10 & $\mathrm{P} 11$ & 19.03 & 11 & 13 & 1.041885 & 218.0978 \\
11 & $\mathrm{P} 12$ & 4 & 26 & 16 & 1.57824 & 164.137 \\
12 & $\mathrm{P} 13$ & 4.1 & 26 & 19 & 2.225565 & 237,2452 \\
13 & $\mathrm{P} 14$ & 18.55 & 6 & 16 & 1.57824 & 175.6581 \\
14 & $\mathrm{P} 15$ & 0.75 & 230 & 13 & 1.041885 & 179,7252 \\
15 & $\mathrm{P} 16$ & 19.03 & 9 & 16 & 1.57824 & 270.3052 \\
16 & $\mathrm{P} 17$ & 18.55 & 5 & 16 & 1.57824 & 146.3818 \\
17 & $\mathrm{P} 18$ & 8.46 & 93 & 13 & 1.041885 & 819.7343 \\
18 & $\mathrm{P} 19$ & 2.38 & 184 & 16 & 1.57824 & 691.1429 \\
19 & $\mathrm{P} 20$ & 18.55 & 5 & 16 & 1.57824 & 146.3818 \\
& TO1AL & & & & & 4284,238 \\
\hline
\end{tabular}

Then based on the known data, it can be calculated the cost for the method of implementing the required in situ concrete as follows:

\section{CONCLUSION}

The in situ implementation method takes 7 days to implement at a cost of Rp.807.867.550,-. While the pre-cast implementation method requires 5 days of implementation at a cost of Rp. $612,345,190,-$

The pre-cast method for abutments is more practical and efficient than the in situ method, because pre-cast concrete is much cheaper and faster than in-situ concrete with a price difference of Rp. 195.552.360,- and a time difference of 2 days. 


\section{REFERENCES}

Annisa, Widya. 2013. Perbandingan Metode Precast dengan Metode Konvensional Ditinjau Berdasarkan Perencanaan Biaya dan Waktu pada Gedung Administrasi Proyek Fasilitas Penunjang Bandara Kuala Namu. Politeknik Negeri Medan .

Ashworth, Allan. 1988. Perencanaan Biaya Bangunan. Jakarta : PT. Gramedia Pustaka Umum.

Cahyono, Fajar. 2010. Study Perbandingan Proyek Pembangunan Gedung Metode Pelaksanaan Precast dengan Metode Konvensional Dilihat dari Segi Waktu dan Biaya. Univeristas Muhammadiyah Surakarta.

Elly T. dan F.X. Supartono. 2000. Kecenderungan Industri Konstruksi Indonesia Masa Depan Dengan Pengembangan Sistem Elemen Pracetak. Jakarta.

Fani, F., dkk. 2012. Analisa Perbandingan Metode Pelaksanaan Cast In Situ dengan Pra Cetak Terhadap Biaya dan Waktu pada Proyek Dian Regency Apartemen. Vol1. No.1 (1-6), 2012.

Ibrahim H. B.2001. Rencana dan Estimate Real of Cost. Jakarta: PT. Bumi Aksara.

Khusnidzar A. dan M.Harry F. 2010. Tugas Akhir Program Analisa Kestabilan Abutment.Semarang.

Najoan, H.C., dkk. 2016. Analisis Metode Pelaksanaan Pelat Precast dan Pelat Konvensional Ditinjau dari Waktu dan Biaya (Studi Kasus: Markas Komando dan Daerah Militer Manado). Vol.4 No. 5 (319-327), Mei 2016.

Purwaningsih, I. dkk.2014. Perbandingan Biaya dan Waktu pada Pelaksanaan Pekerjaan Konstruksi Dengan Beton Konvensional dan Fly Slab (Studi Kasus: Proyek Pembangunan Gedung Politeknik madiun). Vol. 3 No. 4 (850-860), 2014.

R.terr, George dan Leslie W.Rue. 2010. Dasar-Dasar Manajamen. Jakarta: Bumi Aksara.

Soeharto, Imam. 1999. Manajemen Proyek : Dari Konseptual Sampai Operasional. Jakarta: Erlangga.

Wulfram, I. Ervianto. 2006. Eksplorasi Konstruksi Dalam Proyek Konstuksi.Yogyakarta : Andi Offset. 